Accepted Manuscript (AM) of King, R. and Vullnetari, J. (2016) From shortage economy to second economy: An historical ethnography of rural life in communist Albania. Journal of Rural Studies 44: 198-207 [DOI: 10.1016/j.jrurstud.2016.02.010][accepted January 2016; published online 24

February 2016].

\title{
From Shortage Economy to Second Economy: An Historical Ethnography of Rural Life in Communist Albania
}

\begin{abstract}
Few accounts exist of the nature of everyday rural life in communist societies, such as those which existed in Eastern Europe between the end of World War Two and circa 1990. In this paper we use oral-history testimonies from older people to reconstruct an 'historical ethnography' of rural life in Albania, the most isolated and repressive of the East European socialist regimes. We build our analysis around the dialectical relationship between the 'shortage economy', which was all-pervasive and derived from the Albanian regime's Stalinist policy of prioritising mining and heavy industry over consumer goods and agriculture, and the 'second economy' which developed as a bottom-up strategy to overcome some of the imbalances and blockages in the official or 'first' economy. Fieldwork was carried out in clusters of villages and settlements corresponding to cooperatives and a state farm in four locations in different parts of Albania. Within the symbiotic or 'lubricating' relationship between the shortage economy and the second economy, we examine the institutionalised hierarchy of access' that gave some people and groups privileged access to scarce goods, whilst others remained in a marginalised and partially excluded state.
\end{abstract}

Keywords: Albania; communist era; shortage economy; second economy; everyday rural life; oral history

[The Version of Record of this manuscript has been published and is available in Journal of Rural Studies; 24 February 2016; DOI: 10.1016/j.jrurstud.2016.02.010]. 
Accepted Manuscript (AM) of King, R. and Vullnetari, J. (2016) From shortage economy to second economy: An historical ethnography of rural life in communist Albania. Journal of Rural Studies 44: 198-207 [DOI: 10.1016/j.jrurstud.2016.02.010][accepted January 2016; published online 24 February 2016].

\section{Introduction}

What was everyday life really like for the people of Albania during the communist era? This was the question that guided the research we did for this paper. Having already carried out a series of interview-based studies of Albanians who had emigrated during the 1990 s and early 2000 s and settled in Italy and Greece, we were struck by the often ambivalent silences that they drew over their earlier lives, before the country freed itself from its communist yoke in $1991 .{ }^{1}$ We had the impression that the 'dark days' - actually more than forty years - when the country was headed by the 'people's dictator' Enver Hoxha, were unspeakably harsh and to be forgotten, but very few details were forthcoming,

This article draws on our more recent research on the everyday experiences of Albanians who lived most of their lives under a regime that was the most closed and repressive of all the socialist societies of Eastern Europe, ruled by a leader who, by many accounts, mixed vision, charisma, ruthlessness and paranoia in more-or-less equal measure (see, for instance, Hall, 1994: 37-39; Vickers, 1995: 163-209). During 2011-2013 we collected 120 oral-history narratives from older Albanians the length and breadth of the country. Reflecting the fact that the majority of the population were embedded in an economic geography of rural cooperatives and state farms, we concentrate in this paper on the accounts of men and women who lived and worked in settlements that were attached to these collective structures. Our aim was to construct a kind of 'historical ethnography' of everyday rural life during this hidden period. We found that the interviewees were remarkably consistent in their descriptions of the privations and drudgery of rural life before 1990, and in the way they were able to deploy tactics of coping, resistance and even subversion. In order to give a coherent narrative structure to our account, we organise our analysis around two key concepts which have been much discussed in the economic histories of the Soviet Union, Eastern Europe, China, and in Cuba and North Korea today: the shortage economy and the second economy.

Although we can justifiably claim that our Albanian study is unique, it is important to set it within the broader context of a growing literature on rural life in Eastern Europe and the Soviet Union during the communist period. Given the 
Accepted Manuscript (AM) of King, R. and Vullnetari, J. (2016) From shortage economy to second economy: An historical ethnography of rural life in communist Albania. Journal of Rural Studies 44: 198-207 [DOI: 10.1016/j.jrurstud.2016.02.010][accepted January 2016; published online 24

February 2016].

Albanian regime's tenacious faith in Stalinist orthodoxy, there are fruitful comparisons to be made with the literature on Soviet rural collectivisation, especially that which follows an ethnographic approach to everyday realities (Fitzpatrick, 1999; Paxson, 2005; Yurchak, 2006). Stepping outside the Soviet realm, there are important ethnographic studies on Poland, Hungary, Romania and Bulgaria. These use either synchronous (before 1989) or retrospective (oral-history) interviews and fieldwork to build a composite picture of rural life in the socialist period (see, for instance, Creed, 1995a, 1998; Hann, 1980, 1985; Kideckel, 1982, 1993; Kligman and Verdery, 2011; Pasieka, 2012; Swain, 1985; Verdery, 1983). Also very useful are overviews which take a broader historical and geographical sweep across the region (Hann, 2015), as well as more variable-quality edited collections, such as Crowley and Reid (2002) on everyday life in 'socialist spaces', and Todorova (2010) on 'remembering communism'.

Our framing concepts of shortage economy and second economy are not always explicit in the above-cited literature. For this we turn to the definitive papers of Sampson $(1987,1988)$, or to KEnedi's (1981) more detailed ethnography of the hidden economy in Hungary. But what is remarkable in all of this is the lack of attention given to Eastern Europe's most peripheral and little-known state, Albania.

The article now proceeds as follows. First, we briefly review the social-science literature on Albania during the communist era, noting the impossibility of doing 'proper' investigative field research there during that period. Second, we outline our methods of collecting data. The research results are then presented in three sections:

- how the shortage economy affected everyday life in the rural milieu where most Albanians lived at the time;

- how the operation of this shortage economy was structured, but also subverted, through the 'institutionalised hierarchy of access'; and

- how the second economy emerged and functioned both as a 'lubricator' and a 'social mollifier' of rural economic life. 
Accepted Manuscript (AM) of King, R. and Vullnetari, J. (2016) From shortage economy to second economy: An historical ethnography of rural life in communist Albania. Journal of Rural Studies 44: 198-207 [DOI: 10.1016/j.jrurstud.2016.02.010][accepted January 2016; published online 24 February 2016].

The conclusion stresses the originality and significance of the research, both in terms of its methodological approach and in its substantive findings, set once again in a comparative context.

\section{What Do We Know About Albania During the Communist Era?}

Textbooks on the general geography of Eastern Europe published in the 1960s, 1970s and 1980s give Albania short shrift (see Hoffman, 1971; Mellor, 1975; Rugg, 1985; Turnock, 1989); an exception is Pounds (1969: 814-858) but most of his sources and description refer to the pre-communist period. Two scholars, however, have made it part of their life's work to compile detailed portrayals of Albania: Örjan Sjöberg (see his Rural Change and Development in Albania, 1991) and Derek Hall (Albania and the Albanians, 1994). These two monographs, along with many articles by these authors on more specialised economic and demographic themes, are indispensable resources for an understanding of communist-era Albania. Based on a thorough knowledge of Albanian statistics and other sources, together with guided visits to the country, these books synthesise all there is to know about Albanian geography, society and economy up to the early 1990s. Hall (1999) also published a useful review article highlighting some of the key tropes of Albania evident in the extent literature - its 'un-knownness'; an Orientalist interpretation, or rather its marginality to 'the Orient'; and the people's 'elemental' character as 'folk culture' and '(noble) savages'.

More germane to our analysis are some basic economic, social and political facts. An economic colony of Fascist Italy, which coveted its oil, chrome and other mineral deposits, Albania exited World War Two as the least-developed country in Europe. In the chaos surrounding the later years of the war, Enver Hoxha, leader of the Albanian Communist Party, emerged as the dominant political force amongst the partisans seeking liberation for Albania; as a result, Hoxha was able to establish his new government in Tirana in late 1944 (Vickers, 1995: 141-163). Postwar reconstruction was aided by funds from Russia, Yugoslavia and the United Nations Relief and Reconstruction Agency. UNRRA assistance was granted because of the communists' guerrilla operations against the occupying Italians and Germans. But Albania's political and economic allegiances would shift dramatically over the next 
Accepted Manuscript (AM) of King, R. and Vullnetari, J. (2016) From shortage economy to second economy: An historical ethnography of rural life in communist Albania. Journal of Rural Studies 44: 198-207 [DOI: 10.1016/j.jrurstud.2016.02.010][accepted January 2016; published online 24 February 2016].

thirty years: it broke with Yugoslavia as early as 1948 - partly for fear of being incorporated, like Kosovo, into the Yugoslav federation - and with Russia in 1961, following Krushchev's denunciation of Stalin. For the next fifteen years, Albania was economically supported by China, which sent food aid and financed major industrial and infrastructural developments. However, during 1976-1978 Albania-China relations were broken off, partly over questions of ideology connected to China's diplomatic contacts with Western powers. ${ }^{2}$ This positioned Albania on a path of political isolation and economic self-sufficiency which it struggled to maintain, leading to deteriorating living conditions during the 1980s (Sandström and Sjöberg, 1991).

Throughout the communist period, agricultural production remained the mainstay of the population's livelihood; most people lived and worked in rural areas. This was despite the regime's avowed policy of increasing mineral output and creating and boosting industries, expressed in successive five-year plans (Schnytzer, 1982). Yet stringent controls on internal migration - a policy dubbed 'rural retention' by Sjöberg (1994) - kept urban growth to a minimum. Albania's 'underurbanisation' (Sjöberg 1992), whereby the share of the urban population out of the total population remained roughly constant at 30-35 per cent throughout the period 1960-1990, was unique in Europe. 3

Albania started the communist era as the least-technically developed society in Europe, lacking any tradition of scientific agriculture. The rural population, 80 per cent of the total in 1945-1950, was beset by widespread illiteracy, clan-based traditions and a confused landholding structure based on customary law, which mixed widespread peasant micro-holdings with larger-scale religious lands and feudal-style estates. Land redistribution to the landless peasantry in 1945-1946 was seen as a basic plank of the new egalitarian society but, as elsewhere in Eastern Europe, it was merely an interim step which prefigured the collectivisation of rural life. Following the Russian model of kolkhoz and sovkhoz, cooperatives and state farms assumed complete control of the means of agricultural production, save for miniscule private plots. 4 
Accepted Manuscript (AM) of King, R. and Vullnetari, J. (2016) From shortage economy to second economy: An historical ethnography of rural life in communist Albania. Journal of Rural Studies 44: 198-207 [DOI: 10.1016/j.jrurstud.2016.02.010][accepted January 2016; published online 24 February 2016].

Cooperatives were the bedrock of the rural economy and society: between 1960 and 1990 they consistently accounted for $72-76$ per cent of the agricultural area, and for between 42 and 55 per cent of output by value. Influenced by the apparent success of the Chinese communes, cooperatives were progressively enlarged and amalgamated, their number falling from 1,915 in 1959 to 423 by 1978. As the cooperatives grew in size, so greater opportunities arose for division of labour, with more specialised jobs available in sectors like animal husbandry, forage production, fruit-growing and store-keeping, as well as more technically expert personnel such as agronomists and veterinarians. The state-farm sector was concentrated in the newlyreclaimed irrigated coastal plains and in the flat inter-montane basins of the southeast. State farms increased steadily in size and importance during the communist era, reaching a peak of 24 per cent by area and 29 per cent by production in the late 1980s; they were especially geared to intensive agricultural production for urban markets. Family plots were squeezed down to less than 3 per cent by area, renamed 'gardens' in the 1970s (Lelaj 2012: 27), but generated an estimated 20 per cent by value. Private-plot production was complementary to the collective output and hence the two sectors were functionally entwined.

In class terms, the key distinction - as elsewhere in the communist world was between the state farms, which employed proletarianised 'workers', who were salaried employees like workers in factories and mines and, on the other hand, the 'peasant cooperativists' working as members of the cooperatives. Subsequently, the enlargement and greater central control exercised over the cooperatives, combined with the downsizing of private plots, transformed the cooperativists into 'semiproletarianised' peasant workers (Lelaj, 2012: 27). State-farm employees were paid a fixed wage which, whilst lower than that received by the miners and factory workers, was usually higher, and more reliable, than the variable returns paid to cooperative workers, although this comparison is blurred by the variable incidence of selfproduction and state hand-outs.

Collectivisation and state control permitted a general intensification of agriculture through the expansion of irrigation, mechanisation (managed through strategically located 'machine tractor stations'), the intensive use of fertilisers, 
Accepted Manuscript (AM) of King, R. and Vullnetari, J. (2016) From shortage economy to second economy: An historical ethnography of rural life in communist Albania. Journal of Rural Studies 44: 198-207 [DOI: 10.1016/j.jrurstud.2016.02.010][accepted January 2016; published online 24 February 2016].

improved livestock breeding, the electrification of rural areas, and the vigorous mobilisation of youth and other 'voluntary' labour schemes to dig drainage ditches, terrace hillsides and plant fruit trees. Despite these achievements, agricultural planning was undermined by several problems. Production targets were routinely shortfalled, often with dire consequences for the cooperative members. Agricultural productivity was limited by the predominance of rugged upland in Albania's physical geography and by frequent lowland droughts and upland snowfalls (Carter, 1973: 463). Food shortages were endemic, especially of grain, meat, milk and eggs. The collectivised work regime, with its rigid and often petty rules, led to diminishing motivation and effort. Above all there was the difficulty of keeping food production in pace with a total national population that virtually tripled between 1945 (1.1 million) and 1989 (3.2m.).

These agricultural structures were set within an ideological landscape that profoundly influenced people's everyday life experiences. As the Albanian philosopher Artan Fuga (1998) pointed out, Enver Hoxha's project of a communist utopia subjugated, even negated, individuals' thoughts, desires and emotions or dissimulated them into a private, secretive world. Under the 'hegemony of homogenous thought', 'difference' was seen as an ontological problem and therefore as something to be crushed and eliminated, often brutally so, by exile, imprisonment or death. Individuals, and indeed their entire extended families, who had transgressed were categorised as having a 'bad biography' and were thus 'de-classed', deprived of the normal incentives and privileges available to the rest of the population who were 'loyal' communists. Religion, too, was seen as incompatible with the cognitive world of Albanian communism and, in 1967, Albania became the world's first atheist state. 5 Religion was outlawed or, rather, replaced by the 'state religion' of Albanian Marxist-Leninism, called by Lubonja (2002: 100) 'Albanianism', with Enver Hoxha as its secularised deity (Standish 2002: 123). In an epitaph to Hoxha's death in 1985, historian Miranda Vickers memorably wrote:

For over 40 years he had ruled his tiny state isolated in its remote corner of the Balkans. His complex and contradictory personality had forged a unique 
Accepted Manuscript (AM) of King, R. and Vullnetari, J. (2016) From shortage economy to second economy: An historical ethnography of rural life in communist Albania. Journal of Rural Studies 44: 198-207 [DOI: 10.1016/j.jrurstud.2016.02.010][accepted January 2016; published online 24 February 2016].

and lonely path for Albania, and left its imprint on every aspect of Albanian life. Although the country benefited from improved agriculture, industry, and in particular health and education, such initiatives were overshadowed by a horrific legacy of brutal repression... The Albanian people had been cowed into a fearful state of submission, which led them, like their country, to withdraw into themselves with their thoughts kept secret, paranoid and suspicious of all around them (1995: 209).

It is now our task to unlock some of those thoughts and secrets, especially those pertaining to the everyday experiences of working lives in the rural economy.

\section{Methods}

The wider project from which this paper is drawn involved the construction of an ethnography of everyday life in communist Albania by a mixed-method research strategy of oral history, key interviews and archival and documentary evidence, combined with fieldwork in selected urban and rural sites. For this paper we draw on approximately 80 recorded interviews which enable us to reconstruct 'past lives' in the cooperatives and state farms of the rural economy. Fieldwork was in four regions: the remote and mountainous region of Kelmend in the far north of the country; villages between the chromite mining town of Bulqizë and the eastern border with Macedonia; a cluster of villages in Devoll, in south-east Albania; and an area corresponding to a former state farm in southern Albania. This 'multi-sited ethnography' (Marcus, 1995) was strategically designed to reflect a broadly representative cross-section of Albania's physical regions, agricultural regimes and rural economic institutions.

Although we included a number of people who were involved in the management of the cooperatives and the state farms, as well as others who worked in the area as professionals, such as teachers, most of the people we interviewed were 'ordinary' workers. Paraphrasing Sheila Fitzpatrick (1999), who wrote an acclaimed study of the 'everyday Stalinism' of Soviet Russia in the 1930s, we talked mainly to the 'little men and women' who tried to live ordinary lives in the rather extraordinary 
Accepted Manuscript (AM) of King, R. and Vullnetari, J. (2016) From shortage economy to second economy: An historical ethnography of rural life in communist Albania. Journal of Rural Studies 44: 198-207 [DOI: 10.1016/j.jrurstud.2016.02.010][accepted January 2016; published online 24

February 2016].

times of the Albanian purist brand of Marxist-Leninist communism. Spending several weeks lodging in each of the four field locations made it relatively easy to establish contacts for interviews and to network out to a variety of research participants. Lacking a proper population database, we were unable to plan a rigidly defined stratified sample; we were nevertheless careful to diversify the interviewing strategy across equal numbers of men and women, whose ages ranged from mid-40s to late-8os, and whose prior employment exemplified a range of jobs in the rural economy.

Given that the research participants had lived their earlier lives under a regime where 'free speech' was an alien concept, we encountered surprisingly few refusals to participate. Once any initial reluctance had been overcome, interviewees talked freely about how they lived and worked during communism. For most, this was the first time they had talked about themselves in this way and hence their narratives had a freshness about them; indeed we got the impression that even the interviewees themselves were surprised at what they were saying. They often exclaimed, 'I never talked about these things before!' For those who were reticent to talk or unsure how to start, we tried to ease them into the interview by posing simple questions like 'Can you describe what you did on a typical day from the moment you got up in the morning to when you went to bed at night?' or 'Can you remember what you were doing on the day that the news broke that Enver Hoxha had died?'.

Three other points need to be made about the field interviews and how they are to be interpreted. First, it was not possible, in about half the cases, to interview people on their own. This was because most interviews took place in family homes where space was limited and other family members were around. The interview itself often became a social and therefore family occasion. A date and time were fixed, usually in advance, pleasantries and small gifts would be exchanged, and the interviewer(s) would be pressed to have coffee, sweets and raki (a strong alcoholic spirit) and often to stay for a meal. We accepted this hospitality gratefully, since this was an opportunity to gain further insight; in any case, to have refused would have caused offence. These circumstances reflect the reality of doing fieldwork in rural Albania and inevitably undermine an epistemology of representative, individualistic, 
Accepted Manuscript (AM) of King, R. and Vullnetari, J. (2016) From shortage economy to second economy: An historical ethnography of rural life in communist Albania. Journal of Rural Studies 44: 198-207 [DOI: 10.1016/j.jrurstud.2016.02.010][accepted January 2016; published online 24 February 2016].

random-sample interviews with pre-set questions. Rather than a methodological shortcoming, we regard these multi-vocal extended encounters as an asset, since they enabled a more dynamic and continuous interaction and a general enrichment of the narrative data.

Second, we were less interested in the factual accuracy of interviewees' accounts (which often could not be checked anyway), and more in what the narrated impressions represented. Whilst there is one school of oral history (that devoted to an accurate reconstruction of past events) which insists on cross-checking facts, the other view accepts the participants' stories for what they are - stories (Cameron, 2012). Their analytic power resides precisely in what is said and how, and the storied memories of older people about their earlier lives in a completely different social, political and economic system are especially to be valued (Andrews et al., 2009).

This leads us to the final problem with oral-history narratives: the inevitable fact that impressions of the communist era are filtered through the prism of the postcommunist experience of the last twenty-five years. This issue has been much discussed in research situations where people are interviewed about their 'past lives' when such lives contrast markedly with the 'present', and there is a specific literature on the phenomenon of nostalgia - sometimes called 'Ostalgie' - in East European post-socialist contexts (see Betts, 2003; Brunnbauer, 2007; Ekman and Linde, 2005; Pasieka, 2012; Velikonja, 2009). What these studies generally show is that nostalgia can be used as a narrative trope to signal profound dissatisfaction with the present. To quote Velikonja (2009: 535), '[n]ostalgia for socialism does not relate exclusively and precisely to past times, regimes, values and relations, but it embodies a utopian hope that there must be a society that is better than the current one'. Writing about rural Poland, Pasieka (2012) nuances this interpretation by pointing out that what people long for is not the socialist period as such but rather some 'by-products' of that era - specific positive events or particular patterns of rural life including respect and sociality among people. Whilst, as we shall see, there were elements of nostalgia, or at least wistfulness, contained in some of the accounts we recorded, the fact that the communist period was generally remembered in resoundingly negative terms, consistent across the sample, means that this risk of exaggerated or misplaced 
Accepted Manuscript (AM) of King, R. and Vullnetari, J. (2016) From shortage economy to second economy: An historical ethnography of rural life in communist Albania. Journal of Rural Studies 44: 198-207 [DOI: 10.1016/j.jrurstud.2016.02.010][accepted January 2016; published online 24

February 2016].

nostalgia is less of an issue in the Albanian case than it is elsewhere. In fact, none of the literature on socialist nostalgia mentions Albania.

\section{Work and Everyday Life under the Shortage Economy}

Work held the central position in Marxist-Leninist ideology; it was considered the very basis of the class struggle, of culture and identity, and of the 'socialist lifestyle' (Niedermüller, 2004: 27), 'My life has mostly been spent working' is the opening quote in a paper about the life of a miner in socialist Bulgaria (Koleva, 2008: 27), and such a statement resonates with our interviewees, too. Hard physical labour in uncompromising conditions, with extremes of heat and cold, including drought, storms and snow, were the order of the day. Almost all participants recalled backbreaking work in the fields, digging, planting, weeding and harvesting, tending livestock in remote pastures or, in the mountainous north, in the forests cutting wood. Yet the pittances paid were barely enough to live on. Interviewees confirmed the difference between state-farm employees, who received a fixed wage as proletarianised workers, and those who were members of cooperatives - semiproletarianised peasants - who had more variable, and generally lower, incomes.

Amongst dozens of evocative descriptions of 'hard work', the following, from Mrie (pseudonym), female, aged 64, who worked with cattle on a cooperative in Kelmend, is fairly typical:

We had to be at work at $5 \mathrm{am}$, on pain of dismissal. I walked there for more than an hour from my house... in the snow and storms... At work I milked up to thirty cows, with these hands [stretching them out], and now I wonder why they hurt and I can't sleep at night because of the pain. I milked the cows, looked after the calves, cleaned the cowshed, everything... Even in my own house I never cleaned as much as I did at work [laughs]... We had a small break to have some food taken with us and then work again... sometimes we left work at 10 or 11 in the evening... I hardly had time to sleep... My children? The oldest daughter looked after the younger ones... I don't know how to 
Accepted Manuscript (AM) of King, R. and Vullnetari, J. (2016) From shortage economy to second economy: An historical ethnography of rural life in communist Albania. Journal of Rural Studies 44: 198-207 [DOI: 10.1016/j.jrurstud.2016.02.010][accepted January 2016; published online 24

February 2016].

explain to you my suffering... And all we got was three lek [per day]. What could you buy with that? You couldn't even buy milk or cheese.

Beyond the burden of sheer hard work, this interviewee picks up several themes which are relevant to the 'everyday economy' of Albania during communism: the long working days, the dilemma of childcare for working women in that state nurseries and schools only covered certain hours of the day and it was not customary for men to share childcare, the potential health damage that long years of physically demanding toil could bring, and the bare-subsistence wages.

But the fil rouge that ran through all the interview narratives as a fundamental feature of the economic substructure of Albania during this period was shortage - of just about everything except certain agricultural products that happened temporarily to be in season. The most widely espoused argument about shortages in the East European socialist economies is that they were largely structural in nature: '[ $t$ ]he product of an economic system with "soft" budgetary constraints where all producers had an incentive to hoard supplies' (Fitzpatrick, 1999: 42; cf. also Kornai, 1980 for the foundational study on the shortage economy). Soft budget constraints mean that firms or production units that perform poorly will be bailed out, and that financial penalties for what capitalist economists would see as 'irrational' or 'inefficient' behaviour (underinvestment, overemployment etc.) are minimal.

But there are at least two other views about the shortage economy. Synthesising trends across the whole Eastern European and Soviet region, Sampson (1987: 134) argued that the major underlying cause was a shortage of labour, primarily because peasants and workers withheld some labour time from the 'official' economy in order to use it for other, personal, ends such as moonlighting, cultivating private plots, standing in queues, or leisure. This labour withdrawal can be seen as a tactic through which workers in collective farms exercise some, albeit limited, control over their work process. Wierling (1996: 49-50) demonstrated as much for the GDR. This is also the view of Filtzer (1996: 24) who, writing about the decline of the Soviet labour and productive system, argued that workers' absenteeism and other 'negative 
Accepted Manuscript (AM) of King, R. and Vullnetari, J. (2016) From shortage economy to second economy: An historical ethnography of rural life in communist Albania. Journal of Rural Studies 44: 198-207 [DOI: 10.1016/j.jrurstud.2016.02.010][accepted January 2016; published online 24 February 2016].

sanctions' actioned by them were not overt resistance as such, but 'individualised action taken by an essentially atomised and depoliticised workforce'. The background to such action was a highly demoralised population due to the reign of terror throughout the Soviet socialist period, as well as severe socio-economic, political and personal restrictions placed on their lives - an analysis which rings true in the Albanian context.

A third hypothesis is advanced by Shliefer and Vishny (1992): shortages arise because of self-interested behaviour by managers and bureaucrats who collect bribes from dissatisfied consumers chasing scarce products. 'The key feature of socialism', these authors argue (1992: 238), 'is that the decision makers who determine prices and output... do not... keep any of the profits... When there is a shortage of a good, potential customers try to obtain it by offering bribes and favours to the bureaucrats... and managers'. Ledeneva (1998) has written an in-depth study of the 'economy of favours', known in Russian as blat, which also has its equivalent in Albania (mik), as we shall see. But there is a debate to be had here over cause and effect: certainly bribes and favours are an accompaniment to the centrally (mis)managed shortage economy, but are they more of an effect than a fundamental cause?

The above interpretations of the shortage economy are complementary rather than contradictory. In the shortage economy everything is by definition in shortage investment, production, purchasing power, and theoretically too, labour. The issue of labour seems particularly vexed, and its existence in conditions of shortage or surplus can be both relative or absolute according to the political-economic system and the temporal and geographical context. This means that, in a shortage economy where products are in short supply, labour is too since it is not supplied in sufficient quantities to boost output. On the other hand, all socialist enterprises, it turned out, were over-staffed, or inefficiently staffed, resulting in mass unemployment after 1989. In Albania, where population growth was higher than in any other Eastern European country. Sandström and Sjöberg (1991: 935-936) noted that, especially towards the final decade of the communist period, the Albanian economy was far too weak to absorb the annual addition to the labour force of around 45,000 people. Much of the 
Accepted Manuscript (AM) of King, R. and Vullnetari, J. (2016) From shortage economy to second economy: An historical ethnography of rural life in communist Albania. Journal of Rural Studies 44: 198-207 [DOI: 10.1016/j.jrurstud.2016.02.010][accepted January 2016; published online 24

February 2016].

employment deficit was absorbed by the cooperative sector, which acted as an employment buffer. The policy of rural retention kept the countryside continuously overpopulated and, although statistics are impossible to verify, there is evidence that key rural economic indicators, such as agricultural production per capita and investment in the farm sector, were falling by $2-5$ per cent annually during the 1980 s (Pata and Osmani, 1994: 95).

In Albania, as elsewhere in Eastern Europe, the shortage economy was very much a product of political decisions in the economic sphere, one of which was to prioritise industrial and armaments production at the expense of consumer goods. If shortages were more acute and frequent in Albania than elsewhere, it was probably because this country followed the Stalinist model of economic planning - prioritising heavy industry above all else - long after it had been abandoned in the USSR (Schnytzer, 1982: 2). The queues that resulted became a well-remembered feature of all Eastern European societies, giving the impression that the citizens had been cowed into docility - surely queuing did not reflect the heroism of the socialist worker? Verdery (1996: 46) argues that causing queues was one way through which the state demonstrated its power, seizing citizens' time by immobilising their bodies. On the other hand, standing in queues during official working hours was one way in which citizens reclaimed time from the state (Sampson, 1987: 134).

The shortage economy was a daily occurrence in Albania, constantly impinging on, and structuring, people's everyday lives. A certain number of items that formed the food basket of essentials - bread, milk, cooking oil, sugar, rice, pasta, flour and coffee - were rationed and distributed exclusively through local outlets to families registered in the village or neighbourhood. Food rationing persisted longer, and in a more severe form, in Albania than in other communist-era economies. While the distribution of rations through lists ensured a bare minimum supply of basic foods, it also served as a demand control tool. Other foodstuffs, such as fruit, vegetables and fish, were not rationed but sold on a first-come, first-served basis. These were normally seasonal and at times scarce products, prompting people to queue from as early as possible and wait long hours; often supplies ran out quickly, as there was no rationed allocation. The following long interview excerpt, from the 
Accepted Manuscript (AM) of King, R. and Vullnetari, J. (2016) From shortage economy to second economy: An historical ethnography of rural life in communist Albania. Journal of Rural Studies 44: 198-207 [DOI: 10.1016/j.jrurstud.2016.02.010][accepted January 2016; published online 24 February 2016].

narrative of Lira, female, aged 74, in the southern district of Devoll, gives a detailed picture of the food rationing and distribution system, based on her experience of being a store clerk.

The basic foods were distributed according to ration-lists based on the number of souls per household... There were about five or six items sold this way, but our villagers used three of them the most, cooking oil (250ml per person per month), sugar (60og/person) and pasta/spaghetti (500g/person)... There was also rice but it wasn't used that much here... then there was coffee, $100 \mathrm{~g} /$ family, and at times olive oil, half a litre per month per family... I had a list of families and how many persons in each, and when they came to buy these foods I ticked next to their name. On New Year and festive days we were given some extra supplies... Sometimes, if we asked our bosses, we were given an extra one, two, three quintals... and told to give these extras to those we thought most needy, like large families or those who had a special event like a funeral, birth or wedding in the family [...] At the beginning, all these foods were open - the cooking oil was in barrels, as were sugar and rice - and we had to weigh everything, so it was hard and it took me a long time to distribute everything. Later, things were packaged... so all I needed to do was give two or three bottles of oil and a pack of sugar to the family and it was much easier. That way the gossip was eliminated, because before people would complain that I only gave them 400 instead of 500 grams and so on [...] Other items such as hard cheese, halva and pig fat could be purchased without the list; also tomatoes, peppers, cucumbers, water melons, fish, salt, jam, chocolate, cookies... These were sold on a first-come, first-served basis. People stood in queues and bought as much as they could afford... We only had a limited supply of these goods... When things finished, they finished; what could I do? I'd tell the person 'Come back another time'.

Lira's account gives fascinating information about the distribution system under the shortage economy, including mentions of altruistic behaviour to help those most in 
Accepted Manuscript (AM) of King, R. and Vullnetari, J. (2016) From shortage economy to second economy: An historical ethnography of rural life in communist Albania. Journal of Rural Studies 44: 198-207 [DOI: 10.1016/j.jrurstud.2016.02.010][accepted January 2016; published online 24 February 2016].

need, although we do not get any clue as to whether favouritism weighed in these extra allocations. The micro-management of the system involved lots of tedious hard work and, in other interviews, references were made to chaos breaking out in the queues. In the following extract from Lume, female, 66, another store clerk, we get a more vivid idea about the tensions in a cooperative village undergoing rapid population growth yet falling agricultural output.

When I took this job our village had 500 families [households], around 1,500 souls... during the time that I held that job the village increased to 2,600 people, around 600 families. Just one grocery store for all those people... Then for five years I had to sell food for another nearby village, which added another 200 families to my load... I would start at 5 in the morning, because people needed to buy food to go to work... They were in a hurry because they could be turned back [if they were late]... The [cooperative] manager would stand at the edge of the village and stop all those who were late for work and turn them away. So I always had everyone begging me in the morning to serve them first. I had a rule whereby I would give first to those who were rushing to work, then I'd serve the others who'd come for their monthly rations... Then I set another rule that women queued on one side and men on the other. Because it was a mess before; whoever was strongest, they pushed and shoved, they were even pulling each other's hair out! I also didn't want to hear about 'friends' or mik during the working hours... The busiest time was in the evening when people came back from work... It was a big village, people wanted to eat, so I stayed there until 10 or 11 at night.

Returning to Lira's account, she describes another reason for shortages: the lack of storage, especially for foods that needed to be chilled. In the following passage she explains how she received a particular food item, fresh fish, on the basis of her own, conservative, estimate of how much she could sell. She did not have the facilities to store any surplus as there was no fridge in her store. Hence she always accepted a lower supply than required, even if that meant that some families went without. 
Accepted Manuscript (AM) of King, R. and Vullnetari, J. (2016) From shortage economy to second economy: An historical ethnography of rural life in communist Albania. Journal of Rural Studies 44: 198-207 [DOI: 10.1016/j.jrurstud.2016.02.010][accepted January 2016; published online 24

February 2016].

I only got as much supply as I could use... especially in the summer. For example, fish couldn't resist the heat... They would bring me fish from Prespa (nearby lake), ten quintals. But I didn't take ten, only five because, if anything was left over, what could I do with it? ... Or the driver would stay with me until I sold the fish for the day and then he would take back whatever was left over, or go elsewhere and find out if another shop wanted it.

\section{The Institutionalised Hierarchy of Access}

Besides food, other goods were in short supply, too, such as furniture, clothing, fridges, washing machines and televisions, as well as larger social goods like housing, education and vacations. The strategic prioritisation of mineral extraction, heavy industry and armaments by Albania's economic planners downgraded investment in lighter, consumer-oriented manufactured goods, creating chronic shortages across the board. Amongst the strongest memories of life under communism enunciated by the participants in our research were the culture of shortages and the consequent desire for consumer goods that were much more readily available in the West. And Albanians, locked inside their hermit-state by a paranoid dictator, were not able to make the regular shopping trips to the 'other side' that their neighbour-Yugoslavs had been able to make to Trieste since the 1950s (Luthar, 2006).

The multiple scarcities inherent in the shortage economy did not affect all Albanians equally; rather, what emerged was an 'institutionalised hierarchy of access' (Fitzpatrick, 1999) which reinforced existing, but partly hidden, stratifications in Albanian society. Privilege in access to scarce goods and resources was based foremost on loyalty to the Albanian Party of Labour (formerly the Albanian Communist Party). Hence senior communist officials had priority, then came members of the intelligentsia (provided they remained 'pure' and showed no dissident tendencies), then Liberation war veterans, followed by urban and statefarm proletarians, then cooperative 'peasants', leaving the 'de-classed' with little or no access. This hierarchy was recounted to us many times in both 'ordinary' and 'keyinformant' interviews. Household durables, in particular, were distributed only with 
Accepted Manuscript (AM) of King, R. and Vullnetari, J. (2016) From shortage economy to second economy: An historical ethnography of rural life in communist Albania. Journal of Rural Studies 44: 198-207 [DOI: 10.1016/j.jrurstud.2016.02.010][accepted January 2016; published online 24

February 2016].

the authorisation of the pushteti - the people's councils which represented the long arm of state power at the local level.

From dozens of examples, we select two groups of quotes: those relating to the acquisition of TV sets, since the day that the household succeeded in bringing home their first TV is etched in their memories; and those relating to education, since this human-capital resource held so much promise for the future. The severe rationing and privileged access to white goods is probably unique to Albania, and more comparable to North Korea - the frequent modern-day comparator to communistera Albania.

We were given the first TV in our village because we were a martyr's family. My sister-in-law was born on the very day her father fell as a martyr in the war... When we got our TV, only two sets were allocated to our village, and the decision was to give the first to our family because my sister-in-law was a staunch communist. It cost 4,00o lek. We only had half the money and my father went to find the rest among his relatives (Mira, female, 54, former state-farm village, southern Albania).

We got our first TV set... through the pushteti. Uncle Z ['uncle' here is used as a term of respect, not kinship] was, at that time, head of the pushteti here... He told me to put my name down on the list... but I said to him 'Don't joke with me... we don't have the money to buy a TV'. He convinced me by saying that, by the time my turn came, I would have the money... After a year it was my turn - these were black-and-white sets called 'Ilyria'... But I said 'I can't take it, I don't have the money; give it to someone else'. When my husband came home he immediately said 'We'll take it'. They cost 3,500 lek at the time, and we had to borrow most of the money from our relatives in another village. So we brought the TV home. All the neighbourhood children started gathering here because it was one of the first sets in the village... it was just like a cinema (Lida, female, 70, village in southern Albania). 
Accepted Manuscript (AM) of King, R. and Vullnetari, J. (2016) From shortage economy to second economy: An historical ethnography of rural life in communist Albania. Journal of Rural Studies 44: 198-207 [DOI: 10.1016/j.jrurstud.2016.02.010][accepted January 2016; published online 24

February 2016].

Albanian television, right up to 1990, consisted of one channel geared more to propaganda than to entertainment. Watching foreign television, which became more and more widespread during the 1980 s, was regarded as a politically subversive act, so was done in secret, with hidden aerials, special home-made decoders, and blankets placed across windows to prevent the snooping gaze of informers. Italian TV channels were received in the western part of Albania, Greek and Yugoslav TV in the inland border regions. Italian TV was especially fascinating for Albanians, for it offered a televisual landscape of fun, luxury, glamour and free debate, and was largely responsible for framing young Albanians' subsequent migratory projects to see the 'West' and earn money there (Mai, 2001).

Narrations about education had a different timbre, affected not just by families' positioning within the hierarchy of access, as in the first quote below, but also subject to generational and gendered debates within the family - the second quote. The reference to being 'touched' in the first quote again invites comparison with North Korea rather than to other countries in Eastern Europe, although fully in line with Albania's extreme Stalinism.

My father wanted my brother to continue to the secondary school and he went to ask the head of the village, the chief of the pushteti as it was then. He was told that it was not allowed... No one allowed us to continue our studies further at secondary level... just the elementary... because we were 'touched' [të prekun, meaning 'class enemies'] (Marie, female, 38, Kelmend).

I started secondary education when I was much older, after a long delay. Because my father didn't want to let me. 'Why do you need to go to school?' he would say... This is how the mentality was at the time... A long time passed; I was always crying in the house. 'Why did you leave me without schooling?', I kept saying to my parents. Because I was the best pupil in my class. And I used to tell my mother 'If I die, cry for not letting me go to school, nothing else'... And I started school only because in the end she managed to convince my father to let me go (Lule, female, 62, south Albania). 
Accepted Manuscript (AM) of King, R. and Vullnetari, J. (2016) From shortage economy to second economy: An historical ethnography of rural life in communist Albania. Journal of Rural Studies 44: 198-207 [DOI: 10.1016/j.jrurstud.2016.02.010][accepted January 2016; published online 24 February 2016].

The hierarchisation of access was reflected in, and reinforced through, the functioning of a two-tier distribution system - closed and open (cf. Fitzpatrick, 1999, 54-58 on the same system in Stalinist Russia). In the former, rationed goods were distributed through the workplace to those registered on lists as entitled to receive them, as described above. But even here, certain categories of workers, such as miners and timber workers, were privileged. Store-clerk Lume, whom we quoted earlier, went on to describe how the army officers stationed at the border qualified for generous extra rations from her shop, sending a soldier and a mule to pick up the foodstuffs.

In the 'parallel market', luxury goods were available only at so-called 'dollar stores' (valute), located in urban areas near or within tourist hotels, which only accepted foreign currency. These tourist stores existed throughout Eastern Europe. Purchases could only be made by tourists, the Party elite who somehow wangled access to these goods or, as in the case below, families in receipt of remittances from emigrants who had left before the regime banned emigration.

My husband had three paternal uncles in Australia. They had gone there as labour migrants in 1927, not as defectors... They used to send us clothes and sometimes money, fifty or one hundred dollars... We would exchange the money for lek, but sometimes we bought things in the valuta store in Korçë. There, you found goods that were nicer. I bought my daughters-in-law a bag each and an umbrella. These were things you couldn't find in other stores (Bardha, female, 62, Devoll, southern Albania).

\section{The Second Economy as 'Lubricator' and 'Social Mollifier'}

Under such circumstances of acute shortage for practically every daily necessity, let alone more luxury goods and services, the second economy flourished. Broadly defined as 'the informal distribution of goods bypassing the formal bureaucratic system' (Fitzpatrick, 1999: 59), it was also known as the 'unofficial economy' or 'parallel economy' (Grossman, 1977: 25). To varying degrees, it was an integral part 
Accepted Manuscript (AM) of King, R. and Vullnetari, J. (2016) From shortage economy to second economy: An historical ethnography of rural life in communist Albania. Journal of Rural Studies 44: 198-207 [DOI: 10.1016/j.jrurstud.2016.02.010][accepted January 2016; published online 24 February 2016].

of everyday life in all socialist societies. According to Sampson, the second economy competed with, was complementary to, and also hindered the 'first' or 'official' economy. 'The second economies of Eastern Europe', he wrote, 'are at once liberating, lubricating and corrosive' (1987: 122). For some commentators on the East European socialist economies, the lubricating function was all-important; were it not for the second economy, the entire economic and social system would have collapsed much earlier that it did (cf. Gabor, 1979 on the Hungarian second economy). The variety of strategies and subforms within the second economy is made explicit by Verdery (1991: 423). Some were permitted by the state and were hence legal (eg. private plots, within certain strict limits), others were regarded as plainly illegal (the theft of collectively or state-owned stock, absenteeism from work in order to engage in other activities etc.) and yet others constituted a grey area of discretion and favours (eg. the clerk who hides goods under the counter for friends and relatives).

If the second economy was a lubricating response to the shortage economy, the second economy itself need to be 'oiled' in order to function. It is in this context that the informal network of contacts and connections, through which deals were struck, favours exchanged, and blind eyes turned, had a major function. Known in Cold War studies under its Russian name of blat, this system had a key role in redistributing public resources and scarce goods for private use and personal consumption. Difficult to translate into English in a single word or phrase (perhaps the closest would be 'pulling strings'), blat is defined by Ledeneva (1998: 37), in the seminal study on the phenomenon, as 'an exchange of favours or access to public resources in conditions of shortages and a state system of privileges'. The Albanian equivalent is mik, under which the notion of 'exchange of favours' is usually rendered as 'economi e ndereve' or 'economy of honours', thus reflecting the stronger role of honour in Albanian (and the wider Balkan) society, where relations of duty and reciprocity were deeply rooted. ${ }^{6}$

Sampson also suggests (1987: 120-121) that the second economy functioned as a 'social mollifier' by 'channeling political frustration into consumerism, swindling or petty corruption'. Goods distributed through the informal channels of the Albanian second economy were, first and foremost, those produced and owned by 
Accepted Manuscript (AM) of King, R. and Vullnetari, J. (2016) From shortage economy to second economy: An historical ethnography of rural life in communist Albania. Journal of Rural Studies 44: 198-207 [DOI: 10.1016/j.jrurstud.2016.02.010][accepted January 2016; published online 24 February 2016].

the state; those produced privately, such as agricultural and handicraft produce, were in the minority in Albania, in contrast to other Eastern European countries where the importance of personal plots and private enterprise was generally greater.7

Two further remarks can be made in order to highlight the originality of what follows. First, studies of East European second economies by economists are in reality speculative because of the paucity or misleading nature of the available data. Hence the importance of more anthropological-style research into the everyday functioning of the shortage economy, including its non-economic aspects (for example Fitzpatrick, 1999; Kenedi, 1981). Second, none of the literature on the Soviet and East European second economies mentions Albania. People who were in jobs connected to trade, distribution and transportation were in good positions to participate in the second economy. The following quote illustrates how being a store clerk, or being close to a distribution point, gave some individuals an inside track to accessing scarce goods. The speaker is Bardha, who worked in a store in south-east Albania.

Sometimes I had to arrange with the warehouse manager in Bilisht [a nearby town] and beg him to give me an extra roll [of cloth], as my village was big... Here [in the village] I had to do favours to my friends as well. But I had to be careful not to be seen to be doing this openly. What I could do was notify a friend or relative that I had received supplies of a particular good, some clothes or shoes, so they could come and be first in the queue. I couldn't put stuff aside because, if I had an unexpected check, this would be questioned and I could be fired or, worse, face prison.

Goods originating in state-owned production units were obtained and siphoned off for personal use in two main ways. First, by stealing from factories, cooperatives and state farms at various points in the production and distribution chain where surveillance was weaker and, secondly, by buying goods in shops and selling them on at a profit, as we shall discuss later. The theft of state-owned property seems to have been rampant throughout socialist societies. According to 
Accepted Manuscript (AM) of King, R. and Vullnetari, J. (2016) From shortage economy to second economy: An historical ethnography of rural life in communist Albania. Journal of Rural Studies 44: 198-207 [DOI: 10.1016/j.jrurstud.2016.02.010][accepted January 2016; published online 24

February 2016].

Sampson, this emanated from a feeling of alienation of ordinary citizens from their workplaces and from the centrally planned economic system that enveloped and dehumanised them. "The pervasive attitude that "everybody is doing it" and that the elites are getting their own special fringe benefits... creates a moral atmosphere that makes it normal to resort to second economy strategies' (1987: 134). Workplaces were thus seen as institutions to be exploited rather than as collective enterprises wherein property was safeguarded.

In the next quote of this section we hear once again from Bardha. Here she describes the culture of theft in the cooperative where she worked. But she stresses two things which put the process in context: first the small scale of the thefts, in the sense of the tiny amounts that were seen as worth stealing and, secondly, the fact that the cooperative management system, at least in this case, had a humane edge which would absorb the loss for people who were seen as particularly disadvantaged in some way.

In the years when the food crisis became severe, people's standards slipped... People would steal in order to survive. Those who were caught were punished heavily... in some cases by imprisonment. There were two men who stole some sacks of grain and they did six months behind bars... There were also those who would take a pack of beans and hide it... for example, women would stitch a pocket on the inside of their dress, between their hips nobody would check them there... These were small amounts, a few potatoes or half a kilo of beans, they couldn't hide more than that. But it was done out of necessity: they didn't have enough to feed their children... For such small 'mistakes' the punishment would be a fine, or being named and shamed in a fletrrufe [public poster] for damaging socialist property... In some cases when people were very poor... the loss would be passed on to the cooperative. Once a guy who chopped wood in the forest for the cooperative was found to have a certain amount of wood missing - we never learnt what happened to it. Because he was not a devious type, the damage was absorbed by the cooperative and the case was closed. 
Accepted Manuscript (AM) of King, R. and Vullnetari, J. (2016) From shortage economy to second economy: An historical ethnography of rural life in communist Albania. Journal of Rural Studies 44: 198-207 [DOI: 10.1016/j.jrurstud.2016.02.010][accepted January 2016; published online 24 February 2016].

An important role as 'lubricators' of the second economy was played by Albania's Roma minority, who enlarged their traditional roles as horse-breeders and mobile traders to shift goods around the country, using their informal contacts with truck drivers. In addition to supplying horses and mules to the cooperatives, the Roma also traded 'luxury' goods such as watches, gold jewellery, ladies' shoes and accessories, buying and selling at a profit. We interviewed several Roma and below we quote from Mandi (male, 45, southern Albania), whose relatives had been deeply involved in trading networks which spanned the entire country.

My uncle was connected to some traders in Kukës [a town in north-east Albania]... He supplied them with scarves...with gold threads. He had an agreement with the truck drivers who used to transport chrome from Bulqizë [site of the chromite mines] and copper from Spac [a notorious prison camp where the inmates mined copper]... There was good collaboration between the Roma and the drivers... They would hide the goods in their trucks and transport them from Korcë [a town in southern Albania]... When the goods reached their destination, my uncle would get a doctor's sick note for a few days and travel up there [to Kukës] to collect the money and take orders for other goods.

[...]

There was also a big demand for shiny ladies' shoes; these were very scarce... My wife and sister would go to Gjirokastër [an important town in southern Albania] and get twenty or thirty pairs of shoes there, from the store. They would cost 180 lek in the shop, and 120 for sandals. We would give the shop clerk 10 lek more for each pair that we bought. Then they would get back to Korcë on the trucks travelling to Permët. The drivers knew very well that they were traders. Here the goods would be distributed to villages where supplies of such shoes were non-existent. So of course we made our profit, but we were also helping the households [to get what they otherwise could not obtain]. 
Accepted Manuscript (AM) of King, R. and Vullnetari, J. (2016) From shortage economy to second economy: An historical ethnography of rural life in communist Albania. Journal of Rural Studies 44: 198-207 [DOI: 10.1016/j.jrurstud.2016.02.010][accepted January 2016; published online 24 February 2016].

These excerpts from Mandi's interview give an insight into how the Roma lubricated the second economy, and forged synergies between the official economy and the informal market. We also learn of the strategic and catalytic function of truck drivers, whose transgressive role as mobile border-crossers has been noted in other geographic contexts (see Alvarez and Collier, 1994; Hammer, 2002). In Mandi's account, and in those of other Roma we talked to, there was an intriguing balance between risk (of being caught, fined or sent to prison) and profit, but also a general narrative of helping people to acquire things they wanted or needed, often for special occasions like weddings.

\section{Conclusion}

This paper has discussed the shortage economy during Albania's communist period, and the effects of this on the everyday life of people who worked in the cooperatives and state farms which dominated the rural economic geography of the country. By collecting oral-history testimonials from 80 older Albanians living in four distinct areas of the country, we constructed what we have called an 'historical ethnography' - a detailed retrospective of daily life focused around work, shortage, survival and adaptation to the 'system'. This is the originality of our study - the first of its kind in Albania. ${ }^{8}$

Much of our historical-ethnographic evidence has related to the everyday economics and social practices of work. As Koleva (2008) has emphasised, work was the basis of the entire social order under the hegemonic control of the socialist state, and in our research it proved central to the structuring of the life-narratives we collected. Whilst this was true across the East European socialist realm, how does our Albanian material stack up against comparable ethnographic accounts from other parts of the region? Swain (1999) helps us to identify different experiences of socialist agriculture. Poland and Yugoslavia abandoned collectivisation in the 1950 s. At the other end of the doctrinal spectrum, Albania and Romania preserved the Stalinist model: household plots were small and sale of the produce was discouraged or forbidden. Most of the remaining countries went through the Stalinist phase but then developed new models, with varying degrees of success. For instance, Hungary's 
Accepted Manuscript (AM) of King, R. and Vullnetari, J. (2016) From shortage economy to second economy: An historical ethnography of rural life in communist Albania. Journal of Rural Studies 44: 198-207 [DOI: 10.1016/j.jrurstud.2016.02.010][accepted January 2016; published online 24 February 2016].

neo-Stalinist model encouraged private plots as a virtuous expression of the second economy (Swain 1999: 1200-1201). In Albania, by contrast, the second economy was relegated to a more hidden and suppressed function; yet it was all the more vital to survival given the often severe privations of the shortage economy.

We saw that mere survival was the major concern of rural life, with inordinate amounts of time and effort devoted to queuing and devising other methods to acquire both the necessities of life, and the few consumer goods that were available and could be afforded. The contradiction at the heart of communism in Albania and elsewhere in Eastern Europe was apparent in the huge discrepancy between official idealisations of working-class life and the everyday realities that workers confronted (Pittaway, 2005: 5). These contradictions became more visible and painful at times of economic and political crisis, but were always underscored by a fundamentally skewed set of economic planning priorities. Planners concentrated on priority sectors, above all minerals, heavy industry, armaments and defence; agriculture, despite its obvious importance for feeding the population and the workforce, was treated as a residual part of the economy (Schnytzer, 1982: 4-5). Creed (1995b: 845) refers to the 'stinging paradox' whereby the ideological mantra of industrialisation was built on the backs of rural workers who were forced to labour towards their own political and economic marginalisation: requisitions of agricultural produce governed by quotas, negligible agricultural wages, and enduring misery.

In the immediate postwar years, shortages were justified by the Albanian state referring to the inherited poverty of the country and the wartime destruction. Then, the sequence of political alliances with Yugoslavia, Russia and China gave muchneeded financial, material and technical support, including food aid, which helped to alleviate food crises and other shortages. However, after the late 1970s, Albania found itself totally isolated. The downward economic slope that followed the loss of foreign aid, combined with the frustration and alienation of the population over a government that increasingly failed to meet most people's basic needs, prompted individuals and families to intensify their efforts to find their own solutions to their everyday problems. 
Accepted Manuscript (AM) of King, R. and Vullnetari, J. (2016) From shortage economy to second economy: An historical ethnography of rural life in communist Albania. Journal of Rural Studies 44: 198-207 [DOI: 10.1016/j.jrurstud.2016.02.010][accepted January 2016; published online 24 February 2016].

The second economy flourished on the back of the failure of the state-run economy to provide for everyone, and the hierarchisation of access that further subverted the socialist ideal. The second economy should thus be seen as a bottomup solution to a deteriorating economic situation, which expressed itself in a variety of ways: stealing state property, diverting goods from the official to the informal market, bribing persons in key positions, tapping into deeply entrenched family networks, or using ' $m i k$ '. But we also saw how the second economy was closely intertwined with the 'first' economy, both at the functional macro-level of easing structural imbalances and blockages by its 'lubricating' role, and at the individual level of different roles played by strategically positioned actors such as store-keepers, truck-drivers, Roma traders, and others who either turned a blind eye or actively connived in order to claim a slice of the profit. Creed's (1995b: 853) persuasive notion of 'conflicting complementarity' sums up the resolved tension between the shortage and the second economy. The state was constantly torn between its need to control property, production and, above all, labour, and its dependence on the latter to suffer, be resilient, fill in the gaps and oil the wheels of a creaking machine that would otherwise break down. Our detailed exposure of the 'everydayness' of these economic contradictions, tensions, relationships, and pragmatic solutions within a rural setting has gone some way to revoking Schnytzer's (1982: 1) view of the Albanian economy as 'an enigma shrouded in mystery'.

\section{Acknowledgements}

The authors gratefully acknowledge the award of Grant No. Foo230AM from the Leverhulme Trust for the project 'Everyday Life in Communist Albania'. Thanks to the journal's editor and referees for helpful guidance in revising this paper.

\section{References}

Alvarez, R.R. and Collier, G.A., 1994. The long haul in Mexican trucking: traversing the borderlands of the north and the south. American Ethnologist 21, 606627. 
Accepted Manuscript (AM) of King, R. and Vullnetari, J. (2016) From shortage economy to second economy: An historical ethnography of rural life in communist Albania. Journal of Rural Studies 44: 198-207 [DOI: 10.1016/j.jrurstud.2016.02.010][accepted January 2016; published online 24

February 2016].

Andrews, G.J., Kearns, R., Kontos, P. and Wilson, V., 2009. 'Their finest hour': older people, oral histories and the historical geography of social life. Social and Cultural Geography 7, 153-179.

Betts, P., 2003. Remembrance of things past: nostalgia in West and East Germany, 1980-2000. In: Betts, P. and Eghigian, G., Editors. Pain and Prosperity: Reconsidering 20 $^{\text {th }}$ Century German History, Stanford University Press, Palo Alto CA.

Brunnbauer, U., Editor, 2007. Zwischen Amnesie und Nostalgie. Die Erinnerung an den Kommunismus in Südosteuropa. Böhlau, Cologne.

Cameron, E., 2012. New geographies of story and story telling. Progress in Human Geography 36, 573-592.

Carter, F.W., 1973. Albania: some problems of a developing Balkan state. Revue Géographique de l'Est 13, 453-479.

Creed, G., 1995a. Agriculture and the domestication of industry in rural Bulgaria. American Ethnologist 22, 528-548.

Creed, G., 1995b. The politics of agriculture: identity and socialist sentiment in Bulgaria. Slavic Review 54, 843-868.

Creed, G., 1998. Domesticating Revolution. Pennsylvania State University Press, University Park.

Crowley, D. and Reid, S.E., Editors, 2002. Socialist Spaces: Sites of Everyday Life in the Eastern Bloc. Berg, New York.

Ekman, J. and Linde, J., 2005. Communist nostalgia and the consolidation of democracy in Central and Eastern Europe. Journal of Communist Studies and Transition Politics 21, 354-374.

Filtzer, D., 1996. Labor discipline, the use of work time, and the decline of the Soviet system, 1928-1991. International Labor and Working-Class History 50, 9-28.

Fitzpatrick, S., 1999. Everyday Stalinism. Ordinary Life in Extraordinary Times: Soviet Russia in the 1930s. Oxford University Press, Oxford.

Fuga, A., 1998. L’Albanie entre la Pensée Totalitaire et la Raison Fragmentaire. L'Harmattan, Paris.

Gabor, I., 1979. The second (secondary) economy. Acta Oeconomica 22, 291-311. 
Accepted Manuscript (AM) of King, R. and Vullnetari, J. (2016) From shortage economy to second economy: An historical ethnography of rural life in communist Albania. Journal of Rural Studies 44: 198-207 [DOI: 10.1016/j.jrurstud.2016.02.010][accepted January 2016; published online 24

February 2016].

Grossman, G., 1977. The 'second economy’ of the USSR. Problems of Communism 26, 25-40.

Hall, D., 1994. Albania and the Albanians. Pinter, London.

Hall, D., 1999. Representations of place: Albania. Geographical Journal 165, 161-172.

Hammer, F., 2002. A gasoline scented Sindbad: the truck driver as a popular hero in socialist Hungary. Cultural Studies 16, 80-126.

Hann, C., 1980. Tazlar: A Village in Hungary. Cambridge University Press, Cambridge.

Hann, C., 1985. A Village Without Solidarity: Polish Peasants in Years of Crisis. Yale University Press, New Haven.

Hann, C., 2015. Backwardness revisited: time, space, and civilization in rural Eastern Europe. Comparative Studies in Society and History 57, 881-911.

Hoffman, G.W., Editor, 1971. Eastern Europe: Essays in Geographical Problems. Methuen, London.

Kenedi, J., 1981. Do It Yourself: Hungary's Self-Help Economy. Pluto, London.

Kideckel, D., 1982. The socialist transformation of agriculture in a Romanian commune, 1945-62. American Ethnologist 9, 320-340.

Kideckel, D., 1993. The Solitude of Collectivism: Romanian Villagers to the Revolution and Beyond. Cornell University Press, Ithaca.

Kligman, G. and Verdery, K., 2011. Peasants under Siege: The Collectivization of Romanian Agriculture, 1949-1962. Princeton University Press, Princeton.

Koleva, D., 2008. 'My life has mostly been spent working': notions and patterns of work in socialist Bulgaria. Anthropological Notebooks 14, 27-48.

Kornai, J., 1980. Economics of Shortage. North Holland, Amsterdam.

Ledeneva, A.V., 1998. Russia's Economy of Favours: 'Blat', Networking and Informal Exchange. Cambridge University Press, Cambridge.

Lelaj, O., 2012. The proletarianisation of the peasantry: a narrative of socialist modernity in Albania. Ethnologia Balkanica 16, 21-39.

Lubonja, F., 2002. Between the glory of a virtual world and the misery of a real world. In: Schwandner-Sievers, S. and Fischer, B.J., Editors, Albanian Identities: Myth and History, Hurst, London. 
Accepted Manuscript (AM) of King, R. and Vullnetari, J. (2016) From shortage economy to second economy: An historical ethnography of rural life in communist Albania. Journal of Rural Studies 44: 198-207 [DOI: 10.1016/j.jrurstud.2016.02.010][accepted January 2016; published online 24

February 2016].

Luthar, B., 2006. Remembering socialism: on desire, consumption and surveillance. Journal of Consumer Culture 6, 229-259.

Marcus, G., 1995. Ethnography in/of the world system: the emergence of multi-sited ethnography. Annual Review of Anthropology 24, 95-117.

Mai, N., 2001. 'Italy is beautiful': the role of Italian television in Albanian migration to Italy. In: King, R. and Wood, N., Editors, Media and Migration: Constructions of Mobility and Difference, Routledge, London.

Mellor, R.E.H., 1975. Eastern Europe: A Geography of the Comecon Countries. Macmillan, London.

Niedermüller, P., 2004. Arbeit, Identität, Klasse. Der Sozialismus als Lebensentwurf. In: Roth, K. Editor, Arbeit im Sozialismus - Arbeit im Postsozialismus. Erkundungen zum Arbeitsleben im östlichen Europa, LIT Verlag, Munster (Freiburger Sozialanthropologische Studien 1).

Pasieka, A., 2012. Resurrected pigs, dyed foxes and beloved cows. Journal of Rural Studies 28, 72-80.

Pata, K. and Osmani, M., 1994. Albanian agriculture: a painful transition from communism to free market challenges. Sociologia Ruralis 34, 84-101.

Paxson, M., 2005. Solovyovo: The Story of Memory in a Russian Village. Indiana University Press, Bloomington.

Pittaway, M., 2005. Workers and socialist states in postwar Central and Eastern Europe. International Labor and Working-Class History 68, 1-8.

Pounds, N.J.G., 1969. Eastern Europe. Longmans, London.

Rugg, D.S., 1985. Eastern Europe. Longmans, London.

Sampson, S., 1987. The second economy of the Soviet Union and Eastern Europe. Annals of the American Academy of Political and Social Science 493, 120-136. Sampson, S., 1988. 'May you live only by your salary!' The unplanned economy in Eastern Europe. Social Justice 15, 135-159.

Sandström, P. and Sjöberg, Ö., 1991. Albanian economic performance: stagnation in the 1980s. Soviet Studies 43, 931-947.

Schnytzer, A., 1982. Stalinist Economic Strategy in Practice: The Case of Albania. Oxford University Press, London. 
Accepted Manuscript (AM) of King, R. and Vullnetari, J. (2016) From shortage economy to second economy: An historical ethnography of rural life in communist Albania. Journal of Rural Studies 44: 198-207 [DOI: 10.1016/j.jrurstud.2016.02.010][accepted January 2016; published online 24

February 2016].

Shliefer, A. and Vishny, R., 1992. Pervasive shortages under socialism. RAND Journal of Economics 23, 237-246.

Sik, E., 1988. Reciprocal exchange of labour in Hungary. In: Pahl, R., Editor, On Work, Blackwell, Oxford.

Sjöberg, Ö., 1991. Rural Change and Development in Albania. Westview, Boulder, CO.

Sjöberg, Ö., 1992. Underurbanisation and the zero growth hypothesis: diverted migration in Albania. Geografiska Annaler 74B, 3-19.

Sjöberg, Ö., 1994. Rural retention in Albania: administrative restrictions on urbanbound migration. East European Quarterly 28, 205-233.

Standish, M.J.A., 2002. Enver Hoxha's role in the development of socialist Albanian myths. In: Schwandner-Sievers, S. and Fischer, B.J., Editors, Albanian Identities: Myths and History, Hurst, London.

Swain, N., 1985. Collective Farms Which Work? Cambridge University Press, Cambridge.

Swain, N., 1999. Agricultural restitution and co-operative transformation in the Czech Republic, Hungary and Slovakia. Europe-Asia Studies 51, 1199-1219.

Todorova, M., Editor, 2010. Remembering Communism: Genres of Representation. Social Science Research Council, New York.

Turnock, D., 1989. The Human Geography of Eastern Europe. Routledge, London.

Velikonja, M., 2009. Lost in transition: nostalgia for socialism in post-socialist countries. East European Politics and Societies 23, 535-551.

Verdery, K., 1983. Transylvanian Villagers. University of Claifornia Press, Berkeley.

Verdery, K., 1991. Theorizing socialism: a prologue to the 'transition'. American Ethnologist 18, 419-438.

Verdery, K., 1996. What Was Socialism and What Comes Next? Princeton University Press, Princeton.

Vickers, M., 1995. The Albanians: A Modern History. I.B. Tauris, London.

Yurchak, A., 2006. Everything Was Forever, Until It was No More. The Last Soviet Generation. Princeton University Press, Princeton.

Wierling, D., 1996. Work, workers and politics in the German Democratic Republic. International Labor and Working-Class History 50, 44-63. 
Accepted Manuscript (AM) of King, R. and Vullnetari, J. (2016) From shortage economy to second economy: An historical ethnography of rural life in communist Albania. Journal of Rural Studies 44: 198-207 [DOI: 10.1016/j.jrurstud.2016.02.010][accepted January 2016; published online 24 February 2016].

\section{Za, L., 2012. Kombinat. Storia Vita Quotidiana di un Quartiere Simbolo di Tirana. Besa Editrice, Nardò.}

\section{Notes}

\footnotetext{
${ }^{1}$ See the following studies carried out by the authors [removed for blind review]

${ }^{2}$ For a more detailed account of the political economy of Albania during this period, see Hall (1994: 102-140), Schnytzer (1982) and Vickers (1995: 163-203).

3 Calculations from the population statistics in Hall (1994, 92, Table 3. 13) show that the urban share of total population was 30.1 per cent in 1960, rising to 36 per cent in 1990. More remarkably, the share of total population accounted for by the capital, Tirana, actually declined, from 8.4 to 7.5 per cent over the same period. It seems, therefore, that even in an East European context, where ruralurban migration was in general tightly managed at this time, the degree of underurbanisation in Albania was extreme (see Turnock, 1989 for comparative perspectives).

4 Except where otherwise stated, the account below is based on Hall (1994: 119-124), Pata and Osmani (1994) and Sjöberg (1991: 81-165).

5 Prior to the communist purge on religion, Albania had a complex religious make-up: roughly 70 per cent of the population of Muslim heritage, 20 per cent Orthodox Christians (mainly in the far south), and 10 per cent Roman Catholics (in the far north). For details, see Hall (1994: 42-50). In practice, the 'atheist conversion' of the Albanian population meant that religious buildings were closed and either abandoned, destroyed, or converted to other uses; and religious leaders persecuted.

${ }^{6}$ An important form of reciprocity was the mechanism of 'reciprocal labour exchange'. According to Sik (1988), in rural Hungary this arose in situations where households lacked sufficient resources to buy goods and services and did not possess sufficient labour power to rely on self- production, e.g. in private plots.

7 For instance, in Hungary, Romania and Bulgaria, private plots accounted for between 30 and 42 per cent of agricultural output (Sampson, 1987: 125), whereas in Albania it was never more than 20 per cent.

${ }^{8}$ We should mention here an interesting study of the history of the 'Kombinat' industrial complex, built on the south-western edge of Tirana in the early communist years (Za, 2012). The study mainly looks at the socio-economic conditions of this peri-urban district and its population today via a quality-of-life questionnaire survey of 200 families, but also included in the earlier, historical part of the book are interesting insights into life inside the giant textiles complex drawn from 21 oral-history interviews (2012: 33-94).
} 